\title{
PRODUCTIVITY BIAS HYPOTHESIS: NEW EVIDENCE FROM PARALLEL MARKET EXCHANGE RATE
}

\section{James Temitope DADA ${ }^{1}$, Philip Akanni OLOMOLA ${ }^{1}$, Folorunsho Monsur AJIDE ${ }^{2}$}

date of paper receipt:

14.05.2020.

Original Article

${ }^{1}$ Department of Economics, Obafemi Awolowo University, Ile-Ife, Nigeria

${ }^{2}$ Department of Economics, University of Ilorin, Ilorin, Nigeria date of sending to review:

17.05.2020.

doi: 10.2478/eoik-2020-0003 date of review receipt:

25.05.2020.

UDK: 339.194:339.13.017(100)

\section{ABSTRACT}

Aim/ Purpose: The purpose of this study is to investigate Productivity Bias Hypothesis (PBH) in Nigeria using parallel (black) market exchange rate.

Design/Methodology/Approach: The study focused on Naira-Dollar (N/\$) parallel market exchange rate. Quarterly data from 1995 to 2018 were used. Data on domestic productivity and parallel market exchange rate were sourced from Central Bank of Nigeria (CBN) statistical bulletin, 2018 edition. US productivity data was sourced from Federal Reserve Economic Data. Autoregressive Distributed Lag (ARDL) was used as the estimation technique.

Findings: The result reveals that parallel (black) market exchange rate support the presence of productivity bias hypothesis in Nigeria. Furthermore, the purchasing power parity hypothesis was rejected using the conventional unit root test. This implies that using official exchange rate, the study rejects the productivity bias hypothesis.

Research Implications/Limitations: The implication of the study is that exchange rate in Nigeria should be determined freely in the foreign exchange market.

Originality/Value/Contribution: Previous studies have used official exchange rate to test the validity of the productivity bias hypothesis, and the results can be basically described as mixed. Hence, this study differs from extant studies as it examined productivity bias hypothesis using parallel market exchange rate.

\section{Keywords:}

Purchasing Power Parity, Productivity Bias Hypothesis, Productivity Differentials, Parallel Market Exchange Rate, Black Market Exchange Rate 


\section{INTRODUCTION}

The theory of Purchasing Power Parity (Thereafter, PPP) suggests that the ratio of general price in a country is the same with the general price level in another countries. The PPP theory is based on a simplified assumption such as: the law of one price, the arbitrage mechanism and the constant real exchange rate. Since the inception of PPP by Cassel (1921), many studies have focused on the validity or otherwise of the theory (Irandoust, 2017; Bahmani-Oskooee and Wu, 2017; Wu, Bahmani-Oskooee and Nasir, 2015; Wu, Bahmani-Oskooee and Chang, 2016; Arize et al., 2015: Widodo, 2015; Emirmahmutoglu and Omay, 2014; Grossmann, et al., 2014; Chowdhry, 2005). Most of the empirical studies in this area have rejected the PPP theory in strong term (Irandoust, 2017; Widodo, 2015; Ericsson and Irandoust, 2004). One of the important reasons adduced in the literature for the non-validity of PPP is productivity differentials between countries. The productivity differential was first proposed by Balassa (1964) and Samuelson (1964) and has been popularly termed Productivity Bias Hypothesis or Balassa-Samuelson Hypothesis in the literature (Thereafter, $\mathrm{PBH}$ ). The $\mathrm{PBH}$ states that the more productive a country is, the better domestic currency will appreciate in real term. The PBH becomes popular than other factors responsible for non-validity of PPP because it determines the long run economic growth, and also plays important exogenous shocks in explaining fluctuations in real exchange rate (Irandoust, 2017).

The roles played by productivity bias in determining long run growth have led many researchers to examine the validity of PBH. Extant studies on PBH can be broadly classified as mixed (Iyke and Odhiambo, 2017; Halicioglu and Ketenci, 2017; Wang et. al., 2016; Anwar and Ali, 2015; Widodo, 2015; Genius and Tzouvelekas, 2008; Ericsson and Irandoust, 2004; Bahmani-Oskooee and Nasir, 2004; Faria and Ledesma, 2003; Bahmani-Oskooee and Nasir, 2001). As documented by Bahmani-Oskoee and Nasir (2005), studies in this area can be broadly divided into three namely: studies centers on cross-sectional data, studies on time series analysis and studies on panel data. Empirical findings from cross-sectional data and panel data have been regard as inconclusive (Iyke and Odhiambo, 2017; Drine and Rault, 2004; Bahmani-Oskooee and Nasir, 2001). These studies neither support nor invalidate the $\mathrm{PBH}$. On the other hand, must studies on time series analysis have supported the PBH (Halicioglu and Ketenci, 2017; Wang et. al., 2016; Anwar and Ali, 2015; Cardi and Restout, 2015; Bahmani-Oskooee and Nasir, 2005; Rogoff,1992; BahmaniOskooee, 1992; Hsieh, 1982) while few studies rejected the hypothesis (Halicioglu and Ketenci, 2017; Bahmani-Oskooee and Nasir, 2005; Bahmani-Oskooee, 1992). As noted by Bahmani-Oskoee and Gelan (2006) and Bahmani-Oskooee and Nasir (2004) studies on time series data especially in sub-Saharan African countries is rare in number. The few available studies on time series have focused on developed countries with little emphasis on developing countries, especially Nigeria. Since it may be inappropriate to use the conclusion reached from developed countries to generalise the outcome of PHB in developing countries, hence, a study such as this, with focus on Nigeria is necessary. Furthermore, empirical literature on $\mathrm{PBH}$ has shown that most of the panel studies are characterised by pooling countries from different macro-economic environment together and this trend tends to generate inconclusive result (Olomola and Dada, 2017; Ito et al., 1997; Hsieh, 1982). Therefore, it may be inapt to lump countries with such a diverse macro-economic environment together in a study. Therefore, this study focuses on a time series data analysis as suggested by Genius and Tzouvelekas (2008).

Apart from the above, studies on $\mathrm{PBH}$ have used official exchange rate to verify the PBH. It has been found in the literature that official exchange rate is often manipulated by the government and do not reflect the true market picture (Bahmani-Oskoee and Gelan, 2006). This might be one of the reasons $\mathrm{PBH}$ fail to hold in developing countries, especially in Latin America and Africa. Therefore, the parallel market exchange rates (often called black market exchange rate) have been found to reflect the forces of both demand for and supply of exchange rate in the foreign exchange market as it not affected by the distortionary policies of the government. As noted by Ghei and Kamin 
(1996) developing countries like Nigeria, Venezuela among others have been plagued with different exchange rate whether formal or informal, legal or not legal. These exchange rates (most especially, black market) need special attention in identifying the long run real exchange rate. Government in these countries have been found of imposing exchange controls, such as, restricting the volume of certain foreign exchange transactions or on the price at which such transactions are made which led to increase in the parallel market activities.

The rest of the paper is sectionalised as follows. Apart from the introduction presented in section 1 , literature review in section 2, section 3 discusses the empirical model, measure and sources of data. Section 4 presents the empirical result while summary and conclusion wrap up the paper in section 5 .

\section{LITERATURE REVIEW}

As previously explained, productivity bias hypothesis developed by Balassa (1964) and Samuelson (1964) is the most important factor in the literature responsible for the non-validity of purchasing power parity hypothesis. In line with this trend, validity of the hypothesis has continued to attract interest of scholars and policy makers. There is mass of studies on the hypothesis, as the research outputs have continued to yield mixed and inconclusive results. However, the bulk of existing studies did not make use of parallel or black-market exchange rate in their analyses which is found in the literature to reflect the true market price.

Contributing to the debate, Halicioglu and Ketenci (2017) empirically tested the validity of productivity bias hypothesis in eighteen Middle East countries using ARDL bound test and stability test. A country specific study was conducted for the eighteen countries. Out of the eighteen countries, the authors found the hypothesis to hold only in three countries namely Bahrain, Kuwait and Saudi Arabia. Genius and Tzouvelekas (2008) examined the Balassa-Samuelson productivity bias hypothesis in a panel setting of fifty-nine industrialised and developing countries using the random effect technique from 1965 to 1992. The authors found that productivity bias hypothesis fails to hold for most African and some Latin American countries while it holds for OECD countries and Asia. Chowdhry (2012) empirically verified the Balassa-Samuelson hypothesis using annual data for seven SAARC countries. Applying autoregressive distributed lag as the estimation technique, the author found that productivity bias hypothesis holds only in Bangladesh among the seven SAARC countries. In another related study, Chowdhury (2011) examined the BalassaSamuelson hypothesis in Australia using the ARDL cointegration framework between 1950-2003. The author found the validity of the hypothesis in Australia.

Irandoust (2017) investigated the pattern of real exchange rate and productivity bias hypothesis for New Zealand vis-à-vis her major trading partners. Using the symmetry and proportionality conditions with asymptotic theory of panel-VAR models, findings from the study clearly rejected the strong version of the PPP hypothesis but the weak version of the PPP hypothesis receives some support. Furthermore, the author found that productivity differentials among countries are some of the major sources that contribute to the deviation of the PPP-based exchange rate from the equilibrium rate. In another study, Ericsson and Irandoust (2004) examined the validity of purchasing power parity and productivity bias hypotheses for Sweden vis-a-vis nine of its major trading partners namely: Denmark, Finland, France, Germany, Italy, Japan, Norway, the UK, and the US for period between 1973 and 1999. Furthermore, applying panel vector autoregressive model to test the validity of the hypotheses, the authors found that deviation of PPP from the equilibrium exchange rate has a long-run relationship with productivity ratio, implying that as Sweden becomes relatively more productive, the Swedish SEK appreciates in real terms.

Egert (2002) examined the validity of productivity bias hypothesis in the Czech Republic, Hungary, Poland, Slovakia and Slovenia between the period of 1991 and 2000. Applying Vector Autoregression model-based (VAR) cointegration, the results from the study are mixed. The author found long- 
term cointegration relationships between productivity growth and relative prices while the link between relative prices and real exchange rate is found to be much weaker. Similarly, Halicioglu and Ketenci (2017) examined the validity of the hypothesis in seventeen Middle East countries from 1970 to 2015. Applying autoregressive distributed lag as the estimation technique, the results revealed that productivity bias hypothesis only holds in Bahrain, Kuwait and Saudi Arabia.

Applying time series data, Anwar and Ali (2015) examined the validity of productivity bias hypothesis for five South Asian countries namely, Bangladesh, India, Nepal, Pakistan and Sri Lanka. The authors made use of Johansen's cointegration and vector error correction as the estimation techniques. The findings from the study revealed that purchasing power parity theory holds for all countries considered, while productivity bias hypothesis only holds in Bangladesh and Nepal countries. Similarly, Bahmani-Oskooee and Nasir (2004) provided a time series evidence for fortyfour countries between the period of 1960-1990 using ARDL method. The authors concluded that the hypothesis holds in most of the countries considered. Widodo (2015) examined the BalassaSamuelson effect for eight East Asian countriesusing univariate time series, multivariate regression and Johansen multivariate cointegration as estimation techniques. The result from the study revealed that purchasing power parity hypothesis does not hold in the case of the eight East Asian countries. The author concluded that non-traded goods give significant contribution to the PPP deviation.

In Africa, Iyke and Odhiambo (2017) examined the Balassa-Samuelson Hypothesis (BSH) for a panel of eight middle income African countries between 1960 and 2009. The panel of countries selected by the author are Botswana, Ghana, Lesotho, Mauritius, Namibia, Nigeria, South Africa and Zambia. Applying within effect and dynamic panel Generalised Method of Moment as estimation techniques, findings support the $\mathrm{BSH}$ for the group of eight countries.

Bahmani-Oskooee and Miteza (2005) tested the validity of productivity bias hypothesis for a panel of sixty-one countries between 1973 and1990 using techniques such as panel unit-root and panel cointegration analysis. The results from the study revealed validity of the hypothesis. Furthermore, the authors found that the results are not sensitive to classification of the world by regions. In another study, Bahmani-Oskoee and Gelan (2006) used alternative approach to examine the productivity bias hypothesis for three Latin America countries (Chile, Colombia and Costa Rica). The authors found that real black-market exchange rate supported the productivity bias hypothesis in Latin America, while the official exchange rate rejected the hypothesis. In addition, Guo (2010) investigated the hypothesis in Chinese economy from 1985 to2006 using both official and parallel market exchange rate. The author found blackmarket exchange rate to be more consistent with the predictions of the Balassa-Samuelson model than the official exchange rate. The trend in the existing studies has shown that failure to establish the productivity bias hypothesis might be the use of official exchange rate. Thus, this study is different from extant studies by adopting parallel (black) market exchange rate to test the productivity bias hypothesis in Nigeria. 


\section{METHODOLOGY}

This study adopts the empirical model used by Officer (1976), Bahmani-Oskooee and Nasir (2001) and Genius and Tzouvelekas (2008) (For comprehensive explanation on the derivation of the theoretical model, see Officer (1976), Guo (2010)) to validate the productivity bias hypothesis in Nigeria. The model is stated thus:

$$
\ln E X R=\alpha+\beta \ln P R O D+\varepsilon \quad 1
$$

Where lnEXR is logarithm of exchange rate and lnPROD is logarithm of productivity differentials. The exchange rate is real black-market exchange rate in term of foreign currency. Productivity is measure in Nigeria-United State productivity differentials $\left(P R O D=\frac{P R O D_{\text {Nigeria }}}{P R O D_{U S}}\right)$. From equation 1 , Nigeria will experience appreciation in her currency if $\beta$ is positive and significant, thus, affirming the productivity bias hypothesis.

In order, to obtain the short run and run long effect, equation 1 is re-specified in Autoregressive Distributed Lag (ARDL). This approach addresses the problem posed by non-stationary of time series data and give opportunity to examine the cointegration among the variables irrespective of their stationary level. Besides, applying ARDL technique to co-integration also determines the existence of a long-run relationship between the variables having no regard to the order of integration, so far that the order of integration does not exceed one (Awoleye and Dada, 2017; Dada and Olomola, 2017). Furthermore, as noted by Narayan (2005), the small sample properties of the bounds testing approach outweigh the multivariate cointegration.

$\Delta \ln E X R_{t}=\alpha+\sum_{j=1}^{p} \phi_{j} \Delta \ln E X R_{t-j}+\sum_{j=0}^{p} \beta_{j} \Delta \ln P R O D_{t-j}+\lambda_{1} \ln E X R_{t-1}+\lambda_{2} \ln P R O D_{t-1}+\varepsilon_{t} \quad 2$

Where $\phi j$ and $\beta j$ are short run parameters while $\lambda j$ represent the long run relationship. Thus, the Error Correction Term (ECT) form of equation 2 is stated below:

$$
\Delta \ln E X R_{t}=\alpha+\sum_{j=1}^{p} \phi_{j} \Delta \ln E X R_{t-j}+\sum_{j=0}^{p} \beta_{j} \Delta \ln P R O D_{t-j}+\lambda E C T+\varepsilon_{t} \quad 3
$$

The lag length is selected optimally using AIC and SBC model selection criteria. If $\lambda$ in equation 3 is negatively signed and significant, then exchange rate and productivity differentials are cointegrated. The study used quarterly data spanning from 1995Q1-2018Q4. Data on parallel market exchange rate (black market exchange rate) and official exchange rate were source from Central Bank of Nigeria (CBN) statistical bulletin, 2018 edition. These data (exchange rate) were monthly data but were converted to quarterly data using smooth exponential approach. Quarterly data on Nigerian gross domestic product were sourced from Central Bank of Nigeria (CBN) statistical bulletin, 2018 edition. Quarterly data on United State gross domestic product were obtained from Federal Reserve Economic Data (https://fred.stlouisfed.org). Productivity differentials is calculated as the ratio of domestic per capita income to foreign per capita income.

\section{RESULT}

It is imperative to examine the descriptive and statistical properties of the variables before testing the productivity bias hypothesis in Nigeria. Table 1 shows the descriptive statistics of the variables. The measure of central tendency (mean and median) shows that the parallel market exchange rate (BEXR), official market exchange rate (OEXR) and productivity bias (PROD) data are very close, indicating a normal distribution of the variables. Furthermore, all the variables fall within their respective minimum and maximum values. The skewness statistics shows that all variables are positively skewed. Both parallel and official market exchange rate are leptokurtic since their 
kurtosis values are greater than three, while productivity bias is platykurtic because its value is less than three.

Table 2 also shows the degree of correlation among the variables under review. The result shows that parallel market exchange rate and official market exchange rate are highly correlated while other variables have moderate correlation on one another. The high correlation between parallel and official exchange suggests co-movement between the two variables. Parallel market exchange rate exact positive correlation on productivity. This confirm a prior expectation and the theory on the productivity bias hypothesis in Nigeria. The official exchange rate on the other hand as negative effect on productivity in Nigeria.

Apart from the descriptive and statistical properties, the unit root test is presented in Table 3. The result from the unit root tests show that parallel market exchange rate, official market exchange rate and productivity are stationary at first difference using Augmented Dickey Fuller (ADF) and Phillips-Perron (PP) test statistics. The result shows that both parallel market exchange rate rejecting the validity of Purchasing Power Parity (PPP) theory since the variables are not stationary at level. The non-stationary of exchange rates at level further signals the existence of other factors that determine exchange rate such as the productivity deferential.

Table 4 presents the result on the validity of productivity bias hypothesis using the parallel market (black market) in model 1. Since all the variables are expressed in logarithm, the coefficients of the variables are interpreted as the elasticity of exchange rate with respect to productivity differentials. From Table 4 (model 1), PBH holds in both the short run and long run for the parallel market Naira/ Dollar $(\mathrm{N} / \$)$ exchange rate, since the coefficient of productivity bias is positive and significant. The $\mathrm{PBH}$ for Naira/Dollar $(\mathrm{N} / \$)$ is confirmed in the short run by the significant cointegration equation, while in the long run, the F-statistic of the ARDL bound testing is above the upper bound. Furthermore, the results show that exchange rate and productivity differential are cointegrated. In the short run, an increase in Nigerian productivity leads to $0.15 \%$ appreciation in parallel market exchange rate while in the long run, exchange rate appreciated by $1.42 \%$. As a robustness check, the official exchange rate is used to validate the result obtained from the parallel (black market) exchange rate in Table 4 . The result in Table 4 (model 2) shows an insignificant effect of $\mathrm{PBH}$ both in the short and long run. The sign of the parameters rejects the PBH in Nigeria using official exchange rate. These results further confirm the result obtained from the correlation matrix in Table 2.

The validity of $\mathrm{PBH}$ using parallel market exchange rate over official exchange rate also shows that official exchange rate is not freely determined in the market. Official exchange rate, especially in developing countries has been pegged below the equilibrium price, thereby making the activities in the parallel market to strive. In Nigeria, the Naira is tied to the US dollar, thus increasing the activities of the black-market operators popularly called the "Bureau de Change". The exchange rate charge in the parallel market reflect the market price, thus validating the $\mathrm{PBH}$. Furthermore, the study reveals that productivity differentials is a major determinant of black-market exchange rate movement in Nigeria. This empirical finding is supported by the work of Bahmani-Oskooee and Nasir (2001) and Bahmani-Oskoee and Gelan (2006) who found that parallel market exchange rate best explains productivity bias in developing countries. Furthermore, this result is consistence with the work of Genius and Tzouvelekas (2008) who found the absence of productivity bias hypothesis in Nigeria using official exchange rate data.

The diagnostic statistics in Table 4 are in right magnitude. The Lagrange Multiplier (LM) test for the presence of ARCH disturbances is also presented. The LM test shows that the null hypothesis for no ARCH errors is accepted ( $\mathrm{p}>0.05$ ), indicating that there should be no ARCH error left in the standardised residuals. The ARCH test for the present of heteroskedasticity shows the absence of heteroskedasticity in the variance of the errors. 
Table 1. Descriptive statistics

\begin{tabular}{|c|c|c|c|}
\hline & BEXR & OEXR & PROD \\
\hline Mean & 145.36 & 136.18 & 5.07 \\
\hline Median & 130.49 & 131.37 & 5.36 \\
\hline Maximum & 313.58 & 314.09 & 1.17 \\
\hline Minimum & 80.97 & 10.82 & 1.46 \\
\hline Std. Dev. & 61.79 & 75.18 & 3.06 \\
\hline Skewness & 1.50 & 0.56 & 0.31 \\
\hline Kurtosis & 4.57 & 3.46 & 1.93 \\
\hline
\end{tabular}

Where BEXR is parallel market exchange rate, OEXR is official market exchange rate and PROD is productivity bias

Table 2. Correlation Matrix

\begin{tabular}{c|c|c|c|}
$\begin{array}{c}\text { Correlation } \\
\text { Probability }\end{array}$ & BEXR & OEXR & PROD \\
\hline \hline BEXR & 1.00 & & \\
& ---- & & \\
OEXR & 0.96 & 1.00 & \\
& {$[0.00]$} & ---- & \\
PROD & 0.52 & -0.45 & 1.00 \\
& {$[0.00]$} & {$[0.00]$} & ----
\end{tabular}

Table 3. Unit Root Test

\begin{tabular}{|c|c|c|c|c|c|c|}
\hline Variables & ADF & PP & & & & \\
\hline & Level & $1^{\text {st }}$ Difference & Status & Level & $1^{\text {st }}$ Difference & Status \\
\hline BEXR (N/\$) & -1.55 & $-2.62^{\star}$ & $\mathrm{I}(1)$ & 0.82 & $-2.86^{\star}$ & $\mathrm{I}(1)$ \\
\hline OEXR (N/\$) & -1.13 & $-2.88^{\star}$ & $\mathrm{I}(1)$ & -0.07 & $-4.10^{* * *}$ & $1(1)$ \\
\hline PROD & -1.61 & $-3.90^{\star * *}$ & $\mathrm{I}(1)$ & -2.02 & $-11.63^{* * *}$ & $\mathrm{I}(1)$ \\
\hline
\end{tabular}

Where ${ }^{\star \star \star},{ }^{\star \star}$ and ${ }^{\star}$ signifies $1 \%, 5 \%$ and $10 \%$ level of significant 
Table 4. Empirical Result

\begin{tabular}{|c|c|c|}
\hline & $\begin{array}{l}\text { Model 1 } \\
\text { Parallel market Exchange Rate Naira }(\mathrm{N} / \$)\end{array}$ & $\begin{array}{l}\text { Model 2 } \\
\text { Official Market exchange Rate }(\mathrm{N} / \mathrm{\$})\end{array}$ \\
\hline \multicolumn{3}{|c|}{ Short run } \\
\hline DLOG(PROD) & $0.15^{\star}(1.68)$ & $-0.04(0.29)$ \\
\hline CointEq(-1) & $-0.11^{\star \star}(-2.28)$ & $-0.076^{*}(0.06)$ \\
\hline \multicolumn{3}{|c|}{ Long run } \\
\hline LOG(PROD) & $1.42^{\star \star}(-2.15)$ & $-0.52(0.26)$ \\
\hline $\mathrm{C}$ & $-12.47^{* * *}(-3.86)$ & $-17.04^{\star \star \star}(0.00)$ \\
\hline \multicolumn{3}{|c|}{ ARDL Bound Testing } \\
\hline & $\mathrm{I}(0)$ & $\mathrm{I}(1)$ \\
\hline $10 \%$ & 4.04 & 4.78 \\
\hline $5 \%$ & 4.94 & 5.73 \\
\hline $1 \%$ & 6.84 & 7.84 \\
\hline F-Statistic & $6.69^{* *}$ & 1.85 \\
\hline $\mathrm{ARCH}$ & $\begin{array}{c}0.03 \\
{[0.86]}\end{array}$ & $\begin{array}{c}0.04 \\
{[0.84]}\end{array}$ \\
\hline LM & $\begin{array}{c}0.09 \\
{[0.76]}\end{array}$ & $\begin{array}{c}0.02 \\
{[0.88]}\end{array}$ \\
\hline $\mathrm{Q}^{2}$ & $\begin{array}{c}1.89 \\
{[1.00]}\end{array}$ & $\begin{array}{c}1.83 \\
{[1.00]}\end{array}$ \\
\hline
\end{tabular}

Where ${ }^{\star * \star},{ }^{* \star}$ and ${ }^{\star}$ signifies $1 \%, 5 \%$ and $10 \%$ level of significant

( ) are t-statistics

[ ] are probability value

\section{SUMMARY AND CONCLUSION}

Productivity Bias Hypothesis $(\mathrm{PBH})$ states that the more productive a country is, the more the country will experience appreciation in her exchange rate. Thus, extant studies on $\mathrm{PBH}$ in the literature have used official exchange rate to test the validity or otherwise of the $\mathrm{PBH}$. This study differs from previous studies by using the parallel market exchange rate of Naira-US Dollar exchange rate. The parallel market exchange rate often called black market exchange rate has been found in the literature to reflect the true picture of activities foreign exchange market. Quarterly data from 1995Q1 to 2018Q4 were sourced from Central Bank of Nigeria (CBN) statistical bulletin (2018 edition) and Federal Reserve Economic Data (https://fred.stlouisfed.org).

The empirical result suggests that Productivity Bias Hypothesis ( $\mathrm{PBH}$ ) hold using the Naira-Dollar parallel market exchange rate both in the short and long run period. As a robustness check, the official exchange rate of Naira-US Dollar was used to validate the PBH in Nigeria. Official exchange rate rejects the validity of the hypothesis in Nigeria. Findings from this study shows that parallel (black) market exchange rate response more to market fundamentals than official market exchange rate, thus validating the productivity bias hypothesis. Furthermore, the purchasing power parity hypothesis was rejected for both parallel and official market exchange rate using the conventional unit root tests.

The study concludes that policy makers in charge of exchange rate management should allow the rate to be freely determined in the market without the intervention of the government. In addition, economic and social economic policies such as simple tax incentives, research and development training of the labour force etc. would enhance productivity, particularly in the tradable and nontradable sector of the economy in order to gain comparative advantage in real exchange rates in the long-run should be formulated. 


\section{REFERENCES}

Anwar, S. \& Ali, S. Z. (2015). Productivity bias hypothesis: evidence from South Asia, Applied Economics Letters, 22(17), 1389-1394

Arize A. C, Malindretos J, \& Ghosh D. (2015). Purchasing power parity-symmetry and proportionality: evidence from 116 countries. Int Rev Econ Finance, 37:69-85

Awoleye E. O. \& Dada J. T. (2018). Financial Liberalisation and Stock Market Volatility in Nigeria. ICAN Journal of Accounting and Finance (IJAF), 7(1)

Bahmani-Oskooee, M. (1992). A Time Series Approach to Test the Productivity Bias Hypothesis in Purchasing Power Parity. Kyklos, 45: 227-236.

Bahmani-Oskooee, M., \& Miteza, I. (2004). Panel cointegration and productivity bias hypothesis. Journal of Economic Studies, 31(5): $448-456$.

Bahmani-Oskooee, M. \& Nasir, A. B. M. (2001). Panel Data and Productivity Bias Hypothesis. Economic Development and Cultural Change, 49(2), 395-402.

Bahmani-Oskooee, M. \& Nasir, A. B. M. (2002). Corruption, Law and Order, Bureaucracy, and Real Exchange Rates. Economic Development and Cultural Change, 50, 1021-1028.

Bahmani-Oskooee, M. \& Nasir, A. B. M. (2004). ARDL Approach to Test the Productivity Bias Hypothesis. Review of Development Economics, 8(3), 483-488.

Bahmani-Oskooee, M. \& Nasir, A. B. M. (2005). Productivity Bias Hypothesis and The Purchasing Power Parity: A Review Article. Journal of Economic Surveys, 19(4), 671-696.

Bahmani-Oskooee, M. \& A. Gelan (2006), Black market exchange rate and the productivity bias hypothesis, Economics Letters, 91, 243-249

Bahmani-Oskooee, M. \& Niroomand, F. (1996). A Reexamination of Balassa's Productivity Bias Hypothesis. Economic Development and Cultural Change, 45(1), 195-204.

Bahmani-Oskooee, M. \& Rhee, H. J. (1996). More Time Series Support for Balassa's Productivity Bias Hypothesis: Evidence from Korea. Review of International Economics, 4(4), 364-370.

Bahmani-Oskooee, M. \& Nasir, A. B. M (2015). Purchasing Power Parity and the Law of One Price: Evidence from Commodity Prices in Asian Countries. Global Economy Journal, 2015; 15(2), 231-240

Bahmani-Oskooee, M. \& Wu, T. (2017). Purchasing Power Parity in the 34 OECD Countries: Evidence from Quantile-Based Unit Root Tests with both Smooth and Sharp Breaks. Online at https://mpra.ub.uni-muenchen.de/81820/

Balassa, B. (1964). The purchasing power parity doctrine: a reappraisal, Journal of Political Economy, 72, 584- 96

Cardi, O. \& Restour, R. (2015). Imperfect mobility of labor across sectors: a reappraisal of the Balassa-Samuelson effect, Journal of International Economics, 97(2), 249-265

Cassel, G. (1921). The World's Monetary Problems. Skandinaviska Kreditaktiebolaget, Quarterly Report, p. 17 - 21

Chowdhry, T (2012). The real exchange rate and the Balassa-Samuelson hypothesis in SAARC countries: an appraisal. Journal of the Asia Pacific Economy

Chowdhury, K. (2011). Modelling the Balassa-Samuelson Effect in Australia, Australasian Accounting, Business and Finance Journal, 5(1), 77-91

Chowdhry, T., (2005). Asian currency crisis and the generalized PPP: evidence from the Far East. Asian Economic Journal, 19, 137-157

Dada J. T. \& Olomola P. A. (2017). Exchange Rate Volatility and Trade Balance: Evidence from Nigeria. International Journal of Humanities and Social Research, 3(5), 4-10

Drine, I. \& Rault, C. (2004). Does the Balassa-Samuelson Hypothesis Hold for Asian Countries? An Empirical Analysis Using Panel Data and Cointegration Tests, Applied Econometrics and International Development, 4, 59-84

Égert, B. (2002). Does the Productivity-Bias Hypothesis Hold in the Transition? Evidence from Five CEE Economies in the 1990s, Eastern European Economics, 40:2, 5-37, DOI: $10.1080 / 00128775.2002 .11041014$ 
Emirmahmutoglu, F. \& Omay T. (2014). Reexamining the PPP hypothesis: a nonlinear asymmetric heterogeneous panel unit root test. Econ Model, 40, 184-190

Ericsson, J. \& Irandoust, M. (2004). The productivity-bias hypothesis and the PPP theorem: new evidence from panel vector autoregressive models. Japan and the World Economy, 16, 121-138

Faria, J. R. \& Ledesma, M. L. (2003). Testing the Balassa-Samuelson effect: implication for growth and the PPP. Journal of Macroeconomics, 25, 241-253

Genius, M. \& Tzouvelekas, V. (2008). The Balassa-Samuelson Productivity Bias Hypothesis: Further Evidence Using Panel Data, Agricultural Economics Review, 9(2)

Ghei, N. \& Kamin, S. B. (1996). The use of the parallel market rate as a guide to setting the official exchange rate, International Finance Discussion Papers, 564, Board of Governors of the Federal Reserve System (U.S.)

Grossmann A, Simpson M, \& Ozuna T (2014). Investigating the PPP hypothesis using constructed U.S. dollar equilibrium exchange rate misalignments over the post-Bretton Woods period. J Econ Finance, 38, 235-268

Guo, Q. (2010). The Balassa-Samuelson model of purchasing power parity and Chinese exchange rates, China Economic Review, 21, 334-345

Halicioglu, F. \& Ketenci, N. (2017). Testing the Productivity Bias Hypothesis in Middle East Countries, Journal of Economic Studies, https://doi.org/10.1108/JES-04-2017-0104

Hsieh, D.A. (1982). The determination of the real exchange rate: the productivity approach, Journal of International Economics, 12, 355-362

Irandoust, M. (2017). Symmetry, proportionality and productivity bias hypothesis: evidence from panel-VAR models, Economic Change and Restructuring, 50, 79-93

Ito, T., P. Isaard \& S. Symansky (1997). Economic Growth and Real Exchange Rate: An overview of the Balassa-Samuelson Hypothesis in Asia, Working Paper 5979, NBER Working Papers Series, Cambridge, MA

Iyke, B. N. \& Odhiambo, N.M. (2017). An empirical test of the Balassa-Samuelson hypothesis: evidence from eight middle-income countries in Africa, Economic Systems, 41(2), 297-304

Narayan, P.K. (2005). The saving and investment nexus for China: evidence from cointegration tests. Applied Economics, 37, 1979-1990

Officer, L.H., (1976). Productivity bias in purchasing power parity: an econometric investigation. IMF Staff Papers 23, 545-579

Olomola, P. A. \& Dada, J. T. (2017). Real Exchange Rate, Exchange Rate Volatility and Trade Balance in Sub-Saharan African Countries: A Generalized Method of Moment (GMM) Approach. International Journal of Scientific Research and Management (IJSRM), 5(11),7395-7403, https:// doi.org/10.18535/ijsrm/v5i11.08

Rogoff, K. (1992). Traded goods consumption smoothing and the random walk behavior of the real exchange rates, Bank of Japan Monetary and Economic Studies, 10(2), 1-29

Samuelson, P. A. (1964). Theoretical notes on trade problems, Review of Economics and Statistics, 46,145-154

Wang, W., Xue, J., \& Du, C. (2016). The Balassa-Samuelson hypothesis in the developed and developing countries revisited, Economics Letters, 146, 33- 38

Widodo, T. (2015). Purchasing Power Parity and Productivity-Bias Hypothesis. Reviews of Economics and Business Studies,8(2), 9-38. DOI 10.1515/rebs-2016-0001

Wu, J., Bahmani-Oskooee, M. \& Chang, T. (2016). Revisiting purchasing power parity in G6 countries: an application of smooth time-varying cointegration approach, Empirica, DOI 10.1007/ s10663-016-9355-1 